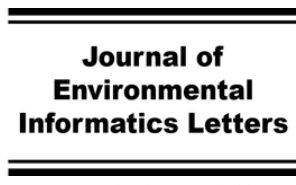

www.iseis.org/jeil

\title{
Handling of Amine-Based Wastewater Produced During Carbon Capture
}

\author{
J. N. Yin ${ }^{1,2 *}$ C. J. An ${ }^{3}$, K. Zhao ${ }^{1}$, Y. K. An ${ }^{4}$, and S. Young ${ }^{5}$ \\ ${ }^{1}$ UR-SaskPower Laboratory of Environmental Processes for Power Industry, Regina, Saskatchewan S4S OA2, Canada \\ ${ }^{2}$ State Key Joint Laboratory of Environmental Simulation and Pollution Control, China-Canada Center for Energy, Environment and Ecology \\ Research, UR-BNU, School of Environment, Beijing Normal University, Beijing 100875, China. \\ ${ }^{3}$ Department of Building, Civil, and Environmental Engineering, Concordia University, Québec H3G 1M8, Canada \\ ${ }^{4}$ Department of Electrical, Electronics and Communications Engineering, Purdue University, Indiana 47907, USA \\ ${ }^{5}$ Faculty of Engineering and Applied science, University of Regina, Regina, Saskatchewan S4S 0A2, Canada
}

Received 5 October 2019; revised 10 November 2019; accepted 30 November 2019; published online 31 December 2019

\begin{abstract}
Carbon capture has been considered one of the most promising technologies to mitigate global warming under climate change. The large-scale implementation of amine-based carbon capture processes requires the development of sustainable handling technology of the waste effluents. The generated wastewater contains significant amounts of ammonia and toxic degradation products, nitroamines and nitrosamines. They both pose great threats to the ecological environment and human health. Monoethanolamine (MEA) is one of the most commonly used absorption solvents in the post-combustion carbon capture process. In order to make a better management strategy, the waste components and the pathways of MEA degradation are demonstrated based on different reference papers and case studies. Moreover, the toxicity and environmental impact of the degradation products are evaluated. The goal of this review is to elucidate potential technologies that can either eliminate the hazardous nature of the amine waste or convert it into marketable products. We categorize these technologies as waste disposal, recycle, reuse, and chemical/biological treatment method. Several applications with a focus on biodegradation technique are examined according to their amine removal performance. The results reveal that bioconversion is a promising technique for handling amine-based wastewater at large-scale.
\end{abstract}

Keywords: Amine-based wastewater, carbon capture, monoethanolamine, solvent degradation, reclamation, biological treatment

\section{Introduction}

Fossil energy combustion like coal, natural gases, and oil is a significant source of greenhouse gas emission, which is closely associated with climate change. To reduce the concentration of carbon dioxide in the atmosphere is of great concern considering its importance in contributing to global warming. It is indicated that about $40 \%$ of global carbon emissions are presently from the coal combustion industry, and this trend will reach a peak around 2030 (Harris and Roach, 2016). The carbon foot-print reduction of related industries is urgent as the world's energy demand continues increasing and fossil fuels remain a reliable source of energy in the foreseeable future (Liu et al., 2018). Carbon capture and storage (CCS) technology has been developed towards achieving this goal.

There are three key technologies for $\mathrm{CO}_{2}$ capture: precombustion, oxyfuel combustion and post-combustion (MacDowell et al., 2010). In post-combustion capture (PCC), $\mathrm{CO}_{2}$ is absorbed by the solvent and separated from other flue gas mixtures after complete combustion with air. The oxyfuel combustion process is performed under high purity oxygen, producing

* Corresponding author. Tel.: + 306-596-0704; fax: + 1-306-5854855.

E-mail address: JYB116@uregina.ca (J. N. Yin).

ISSN: 2663-6859 print/2663-6867 online

(C) 2019 ISEIS All rights reserved. doi:10.3808/jeil.201900018. a flue gas of $\mathrm{CO}_{2} / \mathrm{H}_{2} \mathrm{O}$ steam, which is ready for sequestration. Pre-combustion $\mathrm{CO}_{2}$ capture process converts the fossil fuel into the syngas through gasification or reforming, which can remove $\mathrm{CO}_{2}$ before combustion is completed. Depending on the process, different technologies can be applied to capture and separate $\mathrm{CO}_{2}$ from the flue gas stream, including absorption, adsorption, chemical looping combustion and membrane separation (Zhang et al., 2013; Leung et al., 2014; Gwak et al., 2019). Among these technologies, amine-based post-combustion capture (PCC) is regarded as the most mature technology to mitigate $\mathrm{CO}_{2}$ emission due to its full commercial availability, high absorption capability and relatively simple operation (Wang et al., 2015). Two examples of existing large-scale power plants with amine-based post-combustion capture (PCC) unit are the Petra Nova project in the United States (1.6 million tonnes of $\mathrm{CO}_{2}$ captured annually) and the SaskPower's Boundary Dam power station in Canada (1.3 million tonnes of $\mathrm{CO}_{2}$ captured annually) (Liang et al., 2015; Mazari et al., 2019).

Among various amine solvents in PCC technology, monoethanolamine (MEA) is widely used and regarded as a benchmark solvent, due to its high chemical reactivity, fast adsorption rate and high water solubility (Puxty et al., 2009). However, the high energy penalty, solvent degradation and ecotoxicity problem present enormous challenges for large scale deployment of PCC (Kumar et al., 2014; Dutcher et al., 2015). Therefore, significant research efforts have been directed to the 


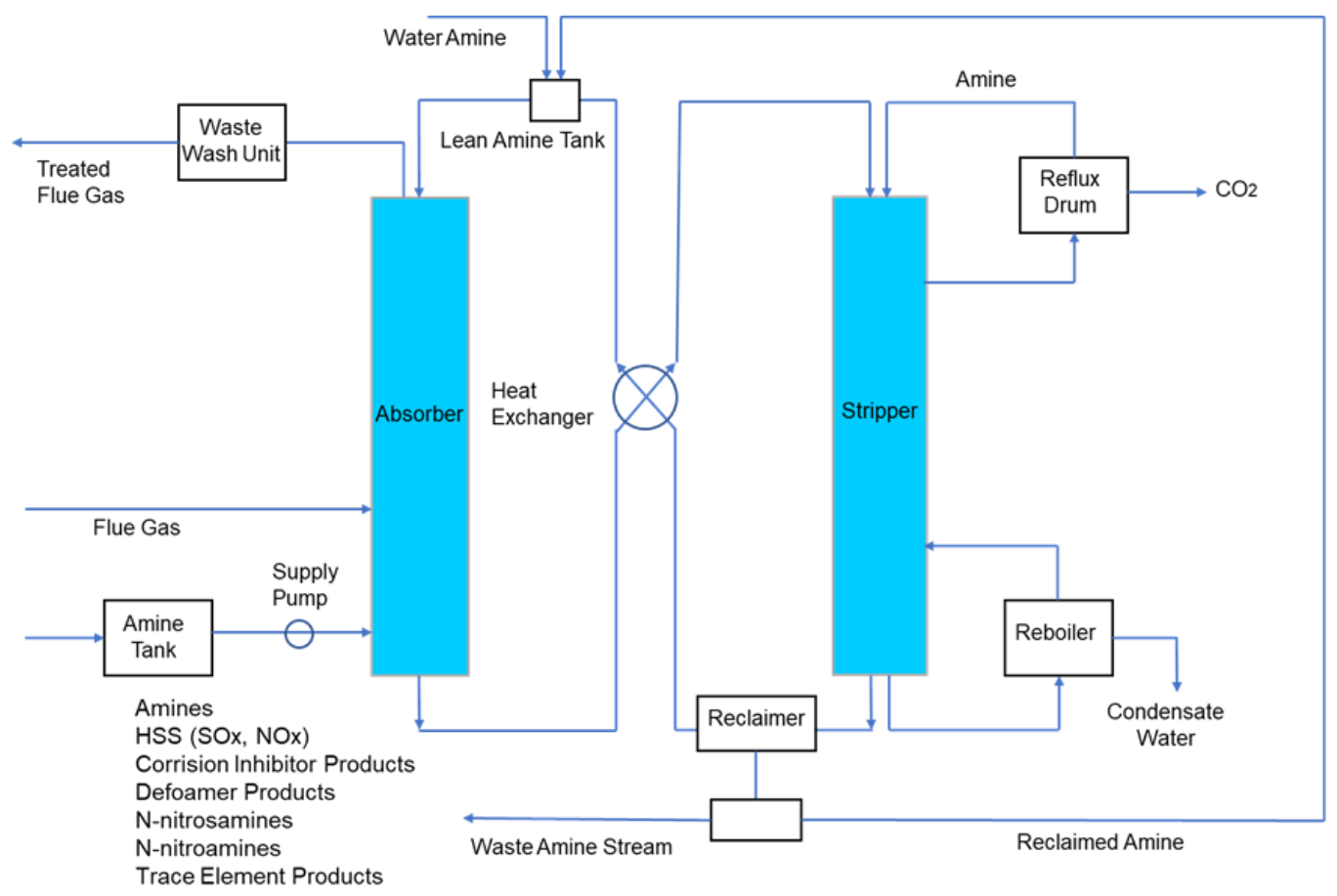

Figure 1. Typical schematic diagram of amine-based PCC process.

development of optimizing solvent with good thermal stability, low cost and toxicity, as well as a high absorption performance (Abu-Zahra et al., 2013). $\mathrm{CO}_{2}$ flue gas passes through the aqueous amine solution creating neutralization reactions and producing degradation products by high thermal exposure. Simultaneously, heat-stable salts are generated from the side reaction between amine-based solvent and reactive species contained in the exhaust gas or the impurities in makeup water (Haws et al, 2001). The reclamation of amine waste, including its degradation products and heat-stable salts, are vital to maintain the efficiency of the process and avoid potential corrosion problems. Also, these degradation products and heat stable salts may induce potential risk to human health and the environment. A comprehensive environmental, health and safety hazard assessment framework of the PCC system has been studied by many researchers to mitigate these impacts (Gjernes et al., 2013; Badr et al., 2017; Kimura et al., 2017; Guan et al., 2019). The majority of the amine waste in the carbon capture process comes from the wastewater of the reclaimer. A slipstream is taken out from the desorber column to remove the amine degradation products and heat-stable salts via commercial reclamation technologies (Shao and Stangeland, 2009). A recent study has estimated that about $1.17 \sim 3.94 \mathrm{~kg}$ reclaimer waste is produced with one tonne of $\mathrm{CO}_{2}$ captured using the thermal reclaiming process (Nurrokhmah et al., 2013). The composition and toxicity of amine waste heavily dependent upon the type of amine solution at use, as well as the contaminants in the flue gases and other process conditions (Thitakamol et al., 2007). In general, this waste amine stream contains ammonia, carbamate polymers, heat-stable salts, organic acids, nitrosamines, nitramines and other degradation products. Thus, handling and re- use of this large quantity of hazardous amine waste have become a major issue concerning the strict enforcement of environmental regulations.

In this review, we will give a comprehensive introduction to the amine-based PCC carbon capture process, and the amine degradation pathways, chemical components and their potential toxicities will be analyzed. Three reclaiming technologies are compared and assessed to purify the amine solvent and drive down the system cost. Different techniques for managing the amine waste are investigated on the basis of existing findings. Waste disposal, recycle, reuse and biological treatment methods are discussed, and their corresponding research gaps are identified. Among these approaches, the feasibility of biodegradation/bioconversion and biological treatment design are presented under various conditions. These information are essential to developing an environmentally safe and cost-effective nitrogen removal system for large-scale implementation of carbon capture technology.

\section{Amine-Based PCC Capture Process}

A typical schematic diagram of amine-based PPC process is illustrated in Figure 1. Absorber and striper column are two major units in this system. $\mathrm{CO}_{2}$ in the gas mixture reacts with the liquid amine solvent in the absorption section, forming carbamate salts while the absorbed $\mathrm{CO}_{2}$ can be released by thermally decomposing the enriched amine in the stripping column. The raw gas containing $\mathrm{CO}_{2}$ passes through the bottom of the absorber, encountering the fresh amine solution coming from the top of the column. Under certain temperature and loading, most $\mathrm{CO}_{2}$ will be removed by chemical absorption. The other 
treated gases will proceed to the washwater unit to reduce amine solvent loss before finally being emitted out. The $\mathrm{CO}_{2}$ loaded solution leaves the absorber from the bottom and gets heated in a cross heat exchanger. It then flows downwards into the stripper and comes upon the hot water vapor generated from the stripper, leading to the release of captured $\mathrm{CO}_{2}$ from the loaded solvent. Finally, the regenerated lean amine solvent is recycled back to the absorber by cooling down through the cross heat exchanger. According to Mazari et al. (2019), a majority of the operating cost involved in the system are amine regeneration and amine solvent cost.

\subsection{Amine-Based Solvent for $\mathrm{CO}_{2}$ Capture}

It is crucial to understand the solvent chemistry in order to develop a reliable and reactive solvent in the PCC system with outstanding absorbent performance. The selection of amine solvents should be addressed based on many criteria, including its thermodynamics, kinetics, absorption solubility, mass transfer, regeneration and solvent stability (Liang et al., 2015). At present, there are a number of amine-based solutions for $\mathrm{CO}_{2}$ capture, which can be classified as primary amine (monoethanolamine, MEA), secondary amine (diethanolamine, DEA), and tertiary amine (N-methyldiethanolamine, MDEA) depending on the number of replaced hydrogen atoms in ammonia (Shao and Stangeland, 2009). Sterically hindered amine (2-amino-2-methyl-1-propanol, AMP) has also emerged as a novel solution with considerable reactivity. During PCC process, $\mathrm{CO}_{2}$ reacts with primary/secondary amine to form a carbamate and protonated amine, consuming $2 \mathrm{~mol}$ amine $/ \mathrm{mol} \mathrm{CO}_{2}$ absorbed, as shown in the following path (McCann et al., 2009; Feron et al., 2010):

Primary amines:

$2 \mathrm{R}_{1} \mathrm{NH}_{2}+\mathrm{CO}_{2} \rightarrow \mathrm{R}_{1} \mathrm{NHCOO}^{-}+\mathrm{R}_{1} \mathrm{NH}_{3}^{+}$

Secondary amines:

$2 \mathrm{R}_{1} \mathrm{R}_{2} \mathrm{NH}+\mathrm{CO}_{2} \rightarrow \mathrm{R}_{1} \mathrm{R}_{2} \mathrm{NCOO}^{-}+\mathrm{R}_{1} \mathrm{R}_{2} \mathrm{NH}_{2}{ }^{+}$

Tertiary and sterically hindered amines may react with $\mathrm{CO}_{2}$ and form bicarbonate by consuming only $1 \mathrm{~mol}$ amine/ mol $\mathrm{CO}_{2}$ absorbed. The reaction path is shown to be (Reynolds et al., 2012):

Tertiary amines:

$\mathrm{R}_{1} \mathrm{R}_{2} \mathrm{R}_{3} \mathrm{~N}+\mathrm{CO}_{2}+\mathrm{H}_{2} \mathrm{O} \rightarrow \mathrm{R}_{1} \mathrm{R}_{2} \mathrm{R}_{3} \mathrm{NH}^{+}+\mathrm{HCO}_{3}^{-}$

Sterically hindered primary or secondary amine:

$\mathrm{R}_{1} \mathrm{NH}_{2} / \mathrm{R}_{1} \mathrm{R}_{2} \mathrm{NH}+\mathrm{CO}_{2}+\mathrm{H}_{2} \mathrm{O} \rightarrow \mathrm{R}_{1} \mathrm{NH}_{3}{ }^{+} / \mathrm{R}_{1} \mathrm{R}_{2} \mathrm{NH}_{2}{ }^{+}+\mathrm{HCO}_{3}^{-}$

Henni et al. (2013) determined the $\mathrm{CO}_{2}$ loading ability in a variety of aqueous amines solvents and concluded that the increased hindrance in amino groups might lead to higher loading capacity, and the trend is primary amines < hindered amines
$<$ secondary amines < tertiary amines < diamines. Although the primary and secondary amines have lower $\mathrm{CO}_{2}$ capacity, they are more generally used for pilot scale PCC due to their rapid reaction speed. For MEA, DEA and MDEA, $\mathrm{CO}_{2}$ absorption rate can be ranked as MEA > DEA > MDEA. Singh et al. (2007) also point out the structural effect of amine solvent on carbon capture performance: (1) alkyl and amine groups play important roles in enhancing the absorption capacity and rate of amine solvents; (2) substitution of hydroxyl groups can improve absorption capacity of the solution but slow down its absorption rate.

Monoethanolamine (MEA) has been commercially employed in the carbon capture industry for a long time. However, it still faces several limitations, such as high energy consumption, low adsorption capacity, and poor thermal stability. Obviously, there is no single solvent that can possess all advanced features in carbon capture. Recently, the blending of amine solvent has shown improved performance in this application. A mixture of $4 \mathrm{~mol} \cdot \mathrm{L}^{-1} \mathrm{MEA} / 1 \mathrm{~mol} \cdot \mathrm{L}^{-1} \mathrm{MDEA}$ amine solvent is carried out at a test plant and the result reveals that this blended solution maintains good chemical stability and consumes less heat-duty than single MEA solvent.

We may recognize that most amine used in $\mathrm{CO}_{2}$ capture can be recycled within the PCC system. However, there is still a portion of amines waste emitted into the atmosphere or degraded to some hazardous and toxic substances that may cause a risk of cancer to animals and humans in the environment. A reclaimer attached to the hot stream stripper is used to collect and treat these amine waste and degradation products.

\subsection{Amine Degradation Products in PCC}

Degradation of amine solution during the PCC process can result in reduced energy efficiency, heavier corrosion problem, increased operation cost, and unwanted environmental emissions (Strazisar et al., 2003; Reynolds et al., 2016). It is estimated that solvent degradation accounts for about $10 \%$ of the total cost in the carbon capture process (Rao and Rubin, 2002). Therefore, it is crucial to understand the degradation mechanisms and the composition of the degradation products. Comprehensive reviews have identified the type of degradations involved in the PCC process. There are two main degradation mechanisms that occur in the system: oxidative amine degradation during $\mathrm{CO}_{2}$ absorption with the presence enough $\mathrm{O}_{2}$ in flue gases and the thermal degradation due to high thermal exposure in the stripper. The type and amount of degradation products inevitably depend on the type of amine used and the quality of flue gas, as well as the combustion process and operation condition (Nurrokhmah et al., 2013). MEA, as the most commonly used amine solvent, has been studied by many articles focusing on its degradation products and degradation pathway. Here we list the oxidation and thermal degradation information of MEA solvent.

\subsubsection{Oxidation Degradation of MEA}

Bello and Idem (2005) have identified an extensive list of 


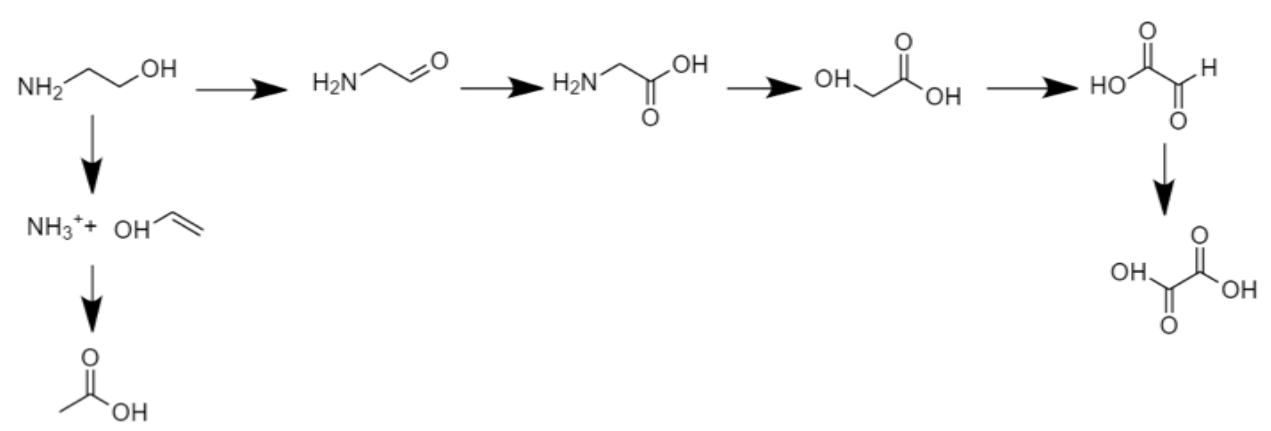

Figure 2. Oxidation degradation of MEA.

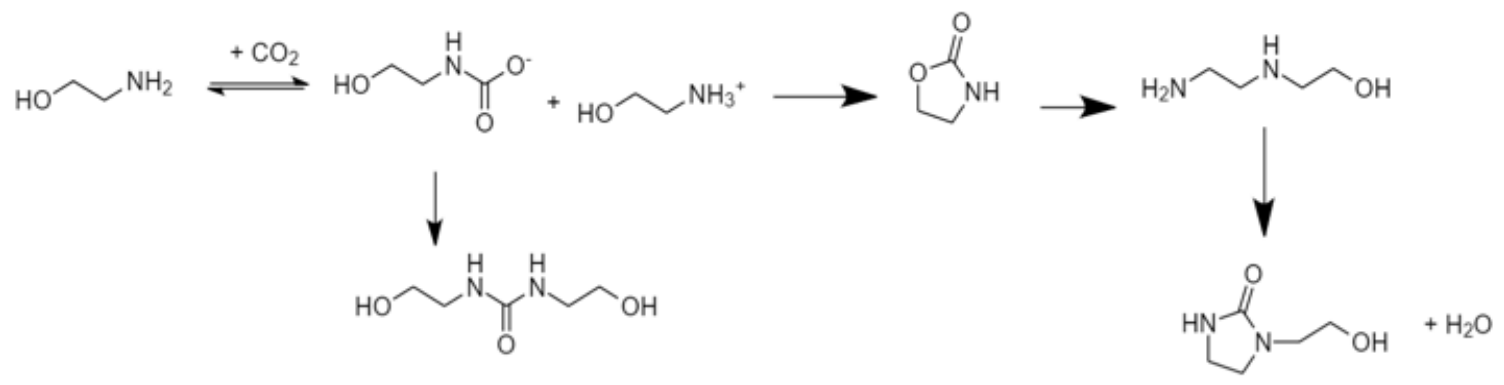

Figure 3. Thermal degradation of MEA.

degradation products at a laboratory scale. The reaction is induced by $\mathrm{O}_{2}$ and produce the oxidized products of amine solvent such as ammonia, organic acid, and aldehydes. The oxidative degradation mechanism is very complex, and it has not been fully understood yet. The most likely amine oxidative degradation reactions are provided in Figure 2. More extensive degradation pathways and unexplained degradation products have been reported by Lawal et al. (2005) and Gouedard et al. (2012). The final oxidative degradation products will mainly be ammonia, formic acids, and some intermediate products like formaldehyde $(\mathrm{HCHO})$ and hydroxyac-etaldehyde $\left(\mathrm{HOCH}_{2}-\right.$ $\mathrm{CHO}$ ). The dissolved metal ions ( $\mathrm{Fe}, \mathrm{Mn}, \mathrm{Cr}, \mathrm{Ni}$, and $\mathrm{Mo}$ ) in the anti-corrosion additives and makeup water can also act as catalysts in the oxidation process. These products are a dominant contributor to solvent degradation, and they have also been detected by the CASTOR pilot plants at Esbjergværket, Denmark (Knudsen et al., 2009). The presence of transition metals can accelerate the oxidative degradation rate of MEA due to the generation of oxide radicals, indicating that metal catalysis is closely related to the oxidation degradation pathway (Goff and Rochelle, 2004). The oxidative degradation is determined by the concentration of $\mathrm{CO}_{2}$, oxygen, and metal ion. Under specific conditions, this process is controlled by the rate of oxygen mass transfer instead of the kinetics of the degradation reactions (Chi and Rochelle, 2002).

\subsubsection{Thermal Degradation of MEA}

Thermal degradation (carbamate polymerization) primarily occurs during MEA- $\mathrm{CO}_{2}$ desorption process. The high presure of $\mathrm{CO}_{2}$ and high temperature in the stripper provide suitable conditions to break down the chemical bonds of amines.
Thermal degradation with $\mathrm{CO}_{2}$ can be summarized into four steps: demethylation reactions, oxazolidinones formation, additions, and ring closures (Lepaumier et al., 2009). Figure 3 summarizes the most commonly reported thermal reactions of MEA. In the initial step, MEA reacts with $\mathrm{CO}_{2}$ in the flue gas and undergoes carbamate formation. Then, this carbamate is supposed to condense and transform into 2-oxazolidone (Gouedard et al., 2012). 2-Oxazolidone successively interacts with another molecule of MEA and forms 1-(2-hydroxyethyl)-2-imidazolidinone (HEIA) (Nurrokhmah et al., 2013). Finally, the cyclic compound N-(2-hydroxyethyl) ethylenediamine (HEEDA) is obtained by intramolecular cyclisation of HEIA (Davis et al., 2009). These degradations include HEIA, HEEDA, MEA-urea, and other polymerization products, making up around $20 \sim 30 \%$ of the total amine solution loss. The rate of thermal degradation is also strongly influenced by $\mathrm{CO}_{2}$ loading, temperature, and amine concentration. Increasing temperature and pressure will increase the amine degradation rate, leading to more degradation byproducts and amine solvent loss.

Besides these two degradation processes, another concern exists in the reclaimer waste is the presence of nitrosamine and nitramines, which is mainly induced by the chemical reaction between $\mathrm{NO}_{\mathrm{x}}$ and primary/secondary/tertiary amine solvent (Chen et al., 2018). Nitrosodiethanolamine (NDELA) and nitrosodimethylamine (NDMA) are two well-known nitrosamines that usually detected as the byproduct of MEA (Fostås et al., 2011). In addition, trace elements from the impurities of coal such as $\mathrm{Cu}, \mathrm{Zn}, \mathrm{As}$, and Se can also be present in the bottom of the reclaimer but with negligible amount. Based on the information from lab-scale degradation experiments (Lepaumier et al., 2011; Nurrokhmah et al., 2013; Thompson et al., 2017), 
Table 1. Composition of MEA Reclaimer Waste

\begin{tabular}{|c|c|c|c|}
\hline Compound \& Quantity & Source & Biodegradability & Hazard classification \\
\hline Water $(20 \sim 33.9 \%)$ & \multirow{4}{*}{ Amine solvent } & \multirow{4}{*}{ Yes } & - \\
\hline Total nitrogen (14\%) & & & - \\
\hline $\mathrm{NH}_{4}+(0.04 \%)$ & & & - \\
\hline MEA $(25 \mathrm{wt} \%)$ & & & Danger \\
\hline 1-(2-hydroxyethyl)-2- imidazolidinone (HEIA) & \multirow{3}{*}{$\begin{array}{l}\text { Thermal degradation } \\
\& \text { carbamate } \\
\text { polymerization }\end{array}$} & \multirow{3}{*}{ Yes } & Warning \\
\hline N-(2-hydroxyethyl)-ethylenediamine (HEEDA) & & & Danger \\
\hline N,N-bis(2-hydroxyethyl) urea (UREA) & & & - \\
\hline Formic acid/formate $\left(\mathrm{HCOOH} / \mathrm{HCOO}^{-}\right)$ & \multirow{9}{*}{$\begin{array}{l}\text { Oxidation degrada- } \\
\text { tion }\end{array}$} & \multirow{9}{*}{ Yes } & Danger \\
\hline Acetic acid/acetate $\left(\mathrm{CH}_{3} \mathrm{COOH} / \mathrm{CH}_{3} \mathrm{COO}^{-}\right)$ & & & Danger \\
\hline Oxalic acid/Oxalate (HOCOCOOH/HOCOCOO$\left.{ }^{-}\right)$ & & & Danger \\
\hline Ammonia/ammonium $\left(\mathrm{NH}_{3} / \mathrm{NH}_{4}{ }^{+}\right)$ & & & Danger \\
\hline Formaldehyde & & & Danger \\
\hline Acetaldehyde & & & Danger \\
\hline Hydroxyethyl formamide (HEF) & & & Warning \\
\hline Hydroxyethyl imidazole (HEI) & & & Warning \\
\hline Hydroxyethyl glycine (HEGly) & & & - \\
\hline Nitrosodiethanolamine (NDELA) $(10 \mathrm{ng} / \mathrm{kg})$ & \multirow{2}{*}{ Reaction with $\mathrm{NOx}$} & \multirow{2}{*}{$\begin{array}{l}\text { Considered to be } \\
\text { biodegradable }\end{array}$} & Danger \\
\hline Nitrosodimethylamine (NDMA) $(5 \mathrm{ng} / \mathrm{kg})$ & & & Danger \\
\hline
\end{tabular}

the commonly recognized degradation products in MEA-based PCC process are shown in Table 1. Different pilots and processing conditions may lead to difference in both the type and the quantity of specific compound. However, the major degradation products of MEA are HEIA, acetic acid, MEA urea, ammonia, and HEEDA. Other contaminants are all at low concentrations in the solvent. However, the reported MEA degradation products in the lab-scale experiment cannot represent real data from the PCC pilot plant. A validate model or simulation at the lab-scale is desired by incorporating proper sampling and analytical regimes into the current amine-based pilot-scale PCC process (Xie et al., 2018).

\subsection{Composition and Toxicity of Amine Waste}

\subsubsection{Amine Waste Composition}

The waste amine stream from the reclaimer contains liquid, solid, and semi-solid fractions. Their composition, toxicity, and volumes are highly dependent on the amine type, flue gas ingredients, and PCC operations. Nurrokhmsh et al. (2013) estimate the components of amine waste sample based on a real case of Fluor's Econamine FGSM coal-fired plant. The flue gas in this plant contains $12.21 \% \mathrm{CO}_{2}$, and $13,123.2$ tonnes of $\mathrm{CO}_{2}$ is captured per day. $1.6 \mathrm{~kg}$ of MEA is required per tonne of $\mathrm{CO}_{2}$ captured, and the expected waste quantity is $39.37 \mathrm{~m}^{3} /$ day on a flow rate basis. The analytical tests on the amine wastewater from pilot-scale plants are inconsistent with the results conducted on the laboratory scale. Table 1 illustrates the main composition of the reclaimer amine waste. The common materials found in the reclaimer bottom are HEIA, 2-oxazolidone, ammonia, acetic acid, and MEA (Strazisar et al., 2001). Thermal degradation products, including HEIA, HEEDA, and DHU have the largest quantity in the amine wastewater. Besides, organic compound $\left(\mathrm{NH}_{4}\right)_{2} \mathrm{SO}_{4}$ dominates a great proportion ( $87 \%$ ) in oxidative degradation products. In addition, another study reports that the formation of nitramines and nitrosamines through $\mathrm{NO}_{\mathrm{x}}$ nitrosation are up to $5 \sim 47 \mathrm{ng} / \mathrm{Nm}^{3}$ under MEA- based pilot plant conditions (da Silva et al., 2013). From the table, we can see most of the components are biodegradable.

\subsubsection{Toxicity of Amine Wastes}

Amine wastewater from the reclaimer is the primary source of amine emissions from PCC. Amine waste produced from carbon capture poses a moderate to severe threat to the human health and ecological system. According to a projected MEA emission rate of 79 tonnes/year, the waste amine can increase the toxicity to freshwater ecosystems by ten times (Veltman et al., 2010). However, amine itself does not pose a great risk to the environment, its wide range of degradation products included nitramines, nitrosamines, carbonyls, amine dimers, heterocyclics, carboxylic acids, and amides are toxic and hazardous (Rohr et al., 2013; Xin et al., 2018). Many researchers have proved that nitramines and nitrosamines are carcinogenic and mutagenic at extremely low levels (Låg et al., 1984; Fjellsbø et al., 2014; Chen et al., 2018). The average genotoxic risk estimation for nitramine/nitrosamine is about $0.45 \mathrm{ng} / \mathrm{m}^{3}$ (Ravnum et al., 2014). Nitrosamines are more carcinogenic but less stable than nitramines, which are 15 times more mutagenic than their nitramines analogues. The Integrated Risk Information System database of USEPA indicates the concentrations (low ng/L) of several nitrosamines in drinking water that are associated with excess lifelong cancer risk (Wagner et al., 2014).

Eide-Haugmo et al. (2012) test the biodegradability and acute toxicity of different amines compounds on marine phytoplankton. The results display a large variation, even when the structure of the compound is similar. Rohr et al. (2013) find significantly increased toxicity in the mice cells, neutrophils, and lymphocytes when exposed to degrade MEA. Liuzinas et al. (2007) evaluate the toxicity of amine contaminated soil on the growth of plants. It is found that phytoremediation can be used for detoxification of waste amine at low concentrations. They also observed the toxicity sensitivity of amine wastes on 
Table 2. Characterization of Raw Waste Amine from the Reference Case

\begin{tabular}{llll}
\hline Raw waste amine & Concentration & Drinking water standard & Concentration \\
\hline COD $(\mathrm{mg} / \mathrm{L})$ & $1050 \sim 1870$ & COD $(\mathrm{mg} / \mathrm{L})$ & $<10$ \\
BOD $(\mathrm{mg} / \mathrm{L})$ & $392 \sim 698$ & BOD $(\mathrm{mg} / \mathrm{L})$ & $<10$ \\
Ammonium & 14320 & TSS $(\mathrm{mg} / \mathrm{L})$ & $<10$ \\
Sulfate $(\mathrm{mg} / \mathrm{L})$ & $<144$ & Turbidity $(\mathrm{NTU})$ & $<0.3$ \\
Ammonia & - & TN $(\mathrm{mg} / \mathrm{L})$ & $<3$ \\
Nitrate $(\mathrm{mg} / \mathrm{L})$ & 186 & TDN $(\mathrm{mg} / \mathrm{L})$ & $<500$ \\
N-Kjeldahl $(\mathrm{mg} / \mathrm{L})$ & 40000 & E. coli $(\mathrm{CFU} / 100 \mathrm{ml})$ & $<200$ \\
pH & $6.5 \sim 7.8$ & Coliforms $(\mathrm{CFU} / 100 \mathrm{ml})$ & $7.0 \sim 8.5$ \\
Temperature $\left({ }^{\circ} \mathrm{C}\right)$ & 43 & pH & $<15$ \\
Alkalinity $(\mathrm{mg} / \mathrm{L})$ & $1450 \sim 1752$ & Temperature $\left({ }^{\circ} \mathrm{C}\right)$ & \\
\hline
\end{tabular}

Table 3. Comparison of Commercially Available Amine Waste Reclamation Technologies

\begin{tabular}{|c|c|c|c|}
\hline & Distillation & Electrodialysis & Ion exchange \\
\hline Applicability & $\begin{array}{l}\text { Removal of solids and non-vola- } \\
\text { tile species }\end{array}$ & Removal of ionic contaminants & Removal of ionic contaminants \\
\hline Waste type & Hazardous, non-aqueous & Non-hazardous, aqueous & Aqueous \\
\hline Volume & Low & Moderate & High \\
\hline Chemical usage & Stoichiometric $\mathrm{NaOH}$ & Stoichiometric $\mathrm{NaOH}$ & $\mathrm{NaOH}$ and $\mathrm{H}_{2} \mathrm{SO}_{4}$ \\
\hline Energy demand & High & Moderate & Low \\
\hline Total cost & High & Moderate & Moderate \\
\hline Requirements & Fuel gas or high temp. & DC power & Regeneration chemicals \\
\hline Advantages & Highly concentrated waste & $\begin{array}{l}\text { Efficient for charged species; lower } \\
\text { chemical consumption }\end{array}$ & Low energy consumption \\
\hline Limitations & $\begin{array}{l}\text { High cost, low amine recovery; } \\
\text { energy intensive; most amines } \\
\text { need vacuum }\end{array}$ & $\begin{array}{l}\text { Cannot remove non-ionic contami- } \\
\text { nants; membrane selection and du- } \\
\text { rability }\end{array}$ & $\begin{array}{l}\text { Cannot remove non-ionic con- } \\
\text { taminants; high salt levels lead } \\
\text { to bed exhaustion }\end{array}$ \\
\hline
\end{tabular}

different microorganisms. Due to the hazardous nature of the amine degradation products, the appropriate treatments and disposal schemes are necessary to reduce these substances to acceptable emission levels and ensure the safe operation of the plant. Biological treatment as an efficient and cost effective method, is becoming a potential trend for waste amine handling at industrial-scale.

\subsubsection{Biodegradability and Characteristic of Amine Waste}

There is extensive research indicating the biodegradability of MEA solvent, including aerobic biodegradation in seawater and soil, biogas production under anaerobic condition, and anoxic nitrogen removal (Henry et al., 2017). Most alkanolamines have a toxicity level of $10 \sim 1000 \mathrm{mg} / \mathrm{L}$, and some of them are biodegradable under aerobic and anaerobic conditions. It is indicated that the degradation rate of MEA-based amine waste is $1.64 \mathrm{~g} / \mathrm{dm}^{3} \cdot \mathrm{h}$, suggesting a strong possibility to treat the carbon capture waste with biological technology (Ohtaguchi et al., 1995). Ammonium is the decomposition product of aerobic digestion, and ammonium, acetic acid, acetaldehyde, formic acid, and ethanol are formed under anaerobic conditions. A syringe batch experiment examines the biodegradability of waste amine under aerobic, micro-aerobic, and anaerobic conditions ( $\mathrm{Li}$ et al., 2008). It shows that more than $90 \%$ of amine COD is removed, and the highest BOD reaction rate is 1.08/day with an initial BOD of $125 \mathrm{mg} / \mathrm{L}$. BOD and COD are important indicators for the biodegradation process, representing the oxygen required for oxidizing the organic compound. From the analysis of wastewater composition, we know there is a lot of sulfate in the degradation products. It may be generated from $\mathrm{SO}_{2}$ captured from the amine solvent and converted to $\left(\mathrm{NH}_{4}\right)_{2} \mathrm{SO}_{4}$. Sulfate will biologically break down into sulfide under anaerobic conditions, which can then form hydrogen sulfide $\left(\mathrm{H}_{2} \mathrm{~S}\right)$ by hydrogen combination. Total nitrogen (TN) is composed of organic nitrogen, ammonia, nitrite, and nitrate. The organic nitrogen can be readily converted to ammonium through the action of microorganisms in the reactor. Phosphorus is essential to the growth of biological organisms, and the orthophosphates (e.g., $\mathrm{HPO}_{4}{ }^{2-}$ ) form are directly available for biological metabolism. Amine wastewater is very acidic with a $\mathrm{pH}$ around 4 , so it must be adjusted by adding alkalinity and maintained at neutral for better biodegradation performance. Although several reports have documented the biological treatment of MEA wastewater, few people list the biological characterization of the real industry reclaimer waste components. Table 2 shows the raw waste amine sample tested in Aker Kvaerner pilot plant at Kårst $\varnothing$ (Norway) (Li et al., 2008), compared with the standard of Canadian drinking water. These waste compositions, biodegradability, and characterization information are useful for (1) investigations of waste amine reuse and recycling activities, (2) design of biological treatment, and (3) evaluation of capital and operation cost derived from the system.

\section{Amine Reclamation Technologies}

Waste reclamation is one of the MEA waste handling practices in the carbon capture process. Waste reclaimer is the unit 


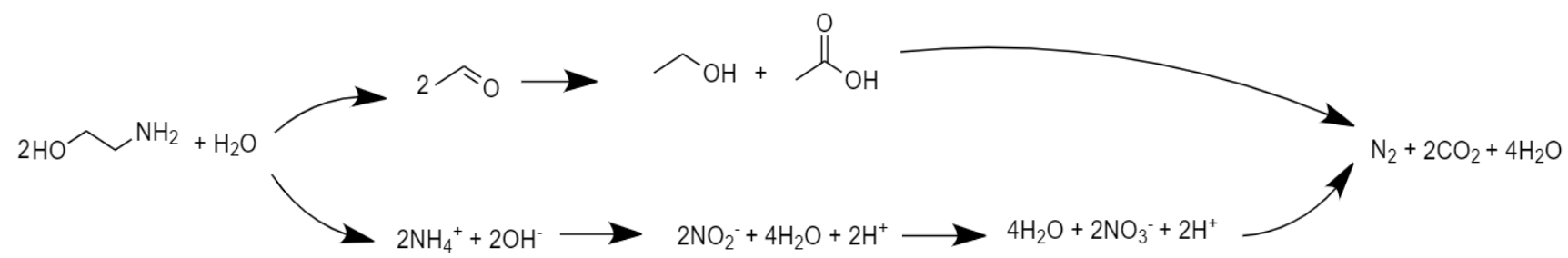

Figure 4. Biodegradation of MEA.

to remove the degradation components from amine solvents, then recycling back the useable amine. Reclaiming the contaminated amine solvent is considered as an ecological friendly technique from the long-term perspective. Amine waste may contain both toxic degradation products and other hazardous heavy metals corrosion inhibitors, including vanadium, antimony, and cyanide compounds. (Thitakamol et al., 2007). The existence of these contaminants leads to reduced carbon adsorption capacity, foaming, fouling, and increased viscosity in operation (Ciferno et al., 2009). In order to purify the amine solvent, three reclaiming technologies have been widely used for the separation process, namely thermal reclaiming (distillation), electrodialysis, and ion exchange. Some advantages and disadvantages are compared in Table 3 (Wang et al., 2015).

Thermal reclamation uses heat energy to recover amine solvent via evaporation, leaving behind the degradation products, heat stable salts, and non-volatile impurities with highboiling points. Canadian Chemical Reclaiming Ltd. reported an amine recovery rate of $90 \sim 95 \%$ from the contaminated solution. However, it is assumed that elevated temperature can result in further solvent and corrosion inhibitors degradations. Also, the thermal reclamation process requires considerable heat consumption, which is approximately $3.0 \sim 3.7 \mathrm{GJ} /$ tonne $\mathrm{CO}_{2}$ captured (Romeo et al., 2008). To overcome these disadvantages, the vacuum thermal reclamation is designed to improve the amine purification efficiency and reduce the operating cost (ElMoudir et al., 2012). Another case study points out that potassium hydroxide can be used to remove sulfate in amine waste by crystallization of $\mathrm{K}_{2} \mathrm{SO}_{4}$ ( $\mathrm{Xu}$ and Rochelle, 2009). Small amounts of waste are generated compared with the process without solvent reclaiming. Ion exchange and electrodialysis reclamation technologies do not need heat input and thus avoid the thermal degradation problem. However, these two options are insufficient in the removal of uncharged components from contaminated amine solvent.

Ion exchange can only separate ionic degradation products and impurities accumulated in the amine system. It consumes fewer chemicals and energy to remove heat stable salts, and the amine recovery rate is up to $99 \%$, especially when the concentration of heat stable salts is low. However, the practice of ion exchange still meets some technical challenges. For example, the loading and regeneration steps involved in the ion exchange process needs large amounts of water for rinsing. Hence, large quantities of diluted waste are produced, which requires further disposal. Additionally, transition metals are likely to cause fouling on the exchange resin (Dumée et al., 2012). Therefore, ion exchange alone may not be satisfactory for $\mathrm{CO}_{2}$ capture applications. The development of a new ion exchange process is needed to purify amine solutions in the system.

Electrodialysis (ED) uses appropriate current and selective-ion membranes to separate charged degradation products between two chambers (Cummings et al., 2007) and can remove $86 \sim 97 \%$ heat stable salts. ED also requires less water usage than ion exchange technology. However, the presence of a small quantity of $\mathrm{CO}_{2}$ in amine solutions can lead to decreased effectiveness and increased energy consumptions (Volkov et al., 2013). Besides, the ion-permeable membrane is temperature sensitive, which means additional cooling is needed to reduce the input temperature of the lean solvent. The high manufacture costs of membranes and fouling problems on the surface also limit the application of ED. Electrodialysis is not capable of removing non-ionic impurities from the system, such as the nitrosamines. Thus, very little information is available for using ED technology to reclaim amine waste in the PCC plant. More work is desired on the membrane modification in accordance with the characteristic of the amine solution.

\section{Waste Amine Treatment Technologies}

\subsection{Waste Disposal, Recycle, and Reuse}

The options used to treat amine wastes could be disposal, recycle, reuse, and biological treatment. Table 4 lists the current application and feasibility for treating MEA wastes. A large amount of amine wastes is generated owing to the degradation of solvents during flue gas scrubbing. Many studies have focused on looking for an economical and environmentally sustainable approach to handle these amine wastes. Landfilling and incineration are two common disposal methods regarding small quantities such liquid wastes. The waste stream could be fed directly to a waste incinerator to destroy amines. However, it is not a cost-effective solution because of the presence of water, resulting in a negative net calorific value (Botheju et al., 2011). In addition, incineration is an additional emission source of $\mathrm{NO}_{\mathrm{x}}$, and the poorly treated amine wastes may release into the environment and harm the local ecosystems.

Co-firing can avoid the potential release of toxic waste amines into the environment employing simultaneous combustion of coal and recycled amine waste into a coal burner (Woods et al., 2006). This option can be considered as an option for recycling reclaimer waste. The calorific value of amine wastes $(16.3 \mathrm{MJ} / \mathrm{kg})$ has a good match with the value of coal $(14 \sim 30$ 
$\mathrm{MJ} / \mathrm{kg}$ ), indicating a suitable characteristic for co-combustion. However, the practical evaluation of this waste recycling method still needs further investigation.

Table 4. Overview of Amine Wastes Handling

\begin{tabular}{ll}
\hline Handling activity & Purpose/technique \\
\hline Disposal & Landfill and incineration \\
Recycle & Co-combustion in coal burner \\
Reuse & $\mathrm{NO}_{\mathrm{x}}$ scrubbing agent \\
Treatment & Peroxidation, UV treatment, photolysis, acti- \\
& vated carbon, biodegradation/bioconversion \\
\hline
\end{tabular}

Ammonia generated from the deposition of amine wastes can be reused to reduce $\mathrm{NO}_{\mathrm{x}}$ emission in incinerators (Botheju et al., 2012; Wang et al., 2014). $\mathrm{NH}_{3}$ and other amino compounds present in wastewater are commonly regarded as the scrubbing agents to transform $\mathrm{NO}_{\mathrm{x}}$ into $\mathrm{N}_{2}$ and water. It has been observed that spraying amines in the combustion process can effectively reduce the formation of harmful nitrogen oxides (NO and $\mathrm{NO}_{2}$ ). Botheju et al. (2012) investigate the possibility of using amine rich wastewater for the selective non-catalytic reduction (SNCR) of $\mathrm{NO}_{\mathrm{x}}$. The results indicate that a $96 \%$ reduction is achieved when TN/NO (total $\mathrm{N}$ to nitric oxide ratio) increases to 8.5 under the optimum temperature of $950{ }^{\circ} \mathrm{C}$. It is noted that this chemical reduction route is only applicable for thermal reclaimed waste, but not an ideal treatment for ED/ion exchange waste due to the low amine concentration in the generated aqueous solution (Ghayur et al., 2019). Using $\mathrm{NO}_{\mathrm{x}}$ as a scrubbing agent at a laboratory scale has been proven to be feasible, but its economic potential still needs to be evaluated.

There are several treatments available for mitigating the toxic degradation products of amine wastes, including nitrosamines and nitramines. Peroxidation, UV treatment, photolysis, biodegradation/bioconversion, adsorption by activated carbon have all been proven as effective methods for the destruction of nitrosamines and nitramines. Among these techniques, UV treatment with oxidants and photolysis are the mainstream in the large-scale continues degradation application. Although biological treatment is time-consuming, its environmental and social benefits cannot be neglected. Based on previous studies, there are some successful biodegradation experiments in handling the amine wastes. A combination of biological treatment and physical adsorption using active carbon is thought to be a promising removal method (Liao et al., 2015). About $90 \%$ of several precursors of $\mathrm{N}$-nitrosamine are removed through this biological activated carbon (BAC) techniques.

\subsection{Biological Treatment}

Biological treatment is an up-and-coming technique in handling wastewater due to the fact that organic waste is rich in carbon and nitrogen, which can be catabolized by the microorganisms as food and energy source. The aerobic condition has the potential to mineralize amines while anaerobic approach can utilize waste amine as a nitrogen source by converting the biomass into chemical fuels (Ghayur et al., 2019). This method has many environmental benefits and economic feasi- bility. Therefore, potential biological treatments are investigated as a sustainable solution to deal with the amine wastewater generated in carbon capture facilities (Lai and Shieh, 1996; Ohtaguchi and Yokoyama, 1997; Strazisar et al., 2003; Mrklas et al., 2004; Ndegwa et al., 2004; Kim et al., 2010; Botheju et al., 2011; Brakstad et al., 2012; Eide-Haugmo et al., 2012; Hauser et al., 2013; Wang et al., 2014; Song et al., 2019).

\subsubsection{Biodegradation/Bioconversion of Amines Waste}

The biodegradability of amines used during carbon capture is extensively assessed under aerobic conditions. Ohtaguchi and Yokoyama (1997) verified that MEA is biodegradable through aerobic process by utilizing the Escherichia coli K12 microbes. The final degradation products will be ammonium ion $\left(\mathrm{NH}_{4}{ }^{+}\right)$and acetaldehyde $\left(\mathrm{CH}_{3} \mathrm{CHO}\right)$. They recognize coenzyme B12 is the major factor initiating this decomposition. Interestingly, it is also found the amine waste solution has a higher degradation rate than pure MEA solution. Under aerobic conditions, ammonium $\left(\mathrm{NH}_{4}{ }^{+}\right)$can be oxidized into nitrite $\left(\mathrm{NO}_{2}{ }^{-}\right)$/nitrate $\left(\mathrm{NO}_{3}{ }^{-}\right)$and denitrified into nitrogen $\left(\mathrm{N}_{2}\right)$. While the acetaldehyde $\left(\mathrm{CH}_{3} \mathrm{CHO}\right)$ then hydrolyzes into ethanol and acetic acid $\left(\mathrm{CH}_{3} \mathrm{COOH}\right)$, which can be uptake by bacteria and turned into $\mathrm{CO}_{2}$ (Zhu et al., 2008). It is known that the degradation rate is related to the degree of adaption to the microbial culture medium (Botheju et al., 2011). By using a readily degradable substrate combined with amine wastes can prevent ammonia and $\mathrm{pH}$ inhibition. And increasing $\mathrm{C} / \mathrm{N}$ ratio may enhance the degradation. Kim et al. (2010) study the adaption time and antimicrobial effects of MEA on biodegradation in wastewater treatment with activated sludge. An aerobic sequencing batch reactor (SBR) is used to test the biodegradation. The results indicate that eight weeks of adaptation is needed for nitrifying ammonium. The removal efficiency reaches $92 \%$ with 9,000 mg/L MEA at the hydraulic retention time (HRT) of 10.5 days. Another research proves that fresh MEA is fully biological degraded within 21 days after phosphate addition in aerobic condition (Mrklas et al., 2004). The degradation products of amine waste, N-nitrosodimethylamine (NDMA), can also be biologically decomposed by axenic strain bacteria under aerobic conditions (Sharp et al., 2005).

The second option to treat amine waste is to use the amines as a nutrient source for microbes in the production of biofuels or chemical fuel under anaerobic conditions. MEA is a typical nitrogen source for hydrogen production (Seifert et al., 2012). Unicellular synechococcus leopoliensis are able to grow in the MEA solution sparged by $\mathrm{CO}_{2}$, which is thought to be suitable for the sequestration of $\mathrm{CO}_{2}$ (Ohtaguchi and Wijanarko, 2002). Different bacterial can convert various amines into a number of products, including ethanol, ammonium, and acetic acid. Wang et al. (2013) successfully run an anaerobic bioreactor over a year for converting waste MEA to methane. By running this MEA-based PCC coal power plant for two years, they observe the formation of ammonia in addition to methane (Wang et al., 2014). Also, the toxicity of MEA wastes decrease by $10 \sim 126$ folds through anaerobic degradation. It means that ammonia removal, together with anaerobic digestion of MEA 


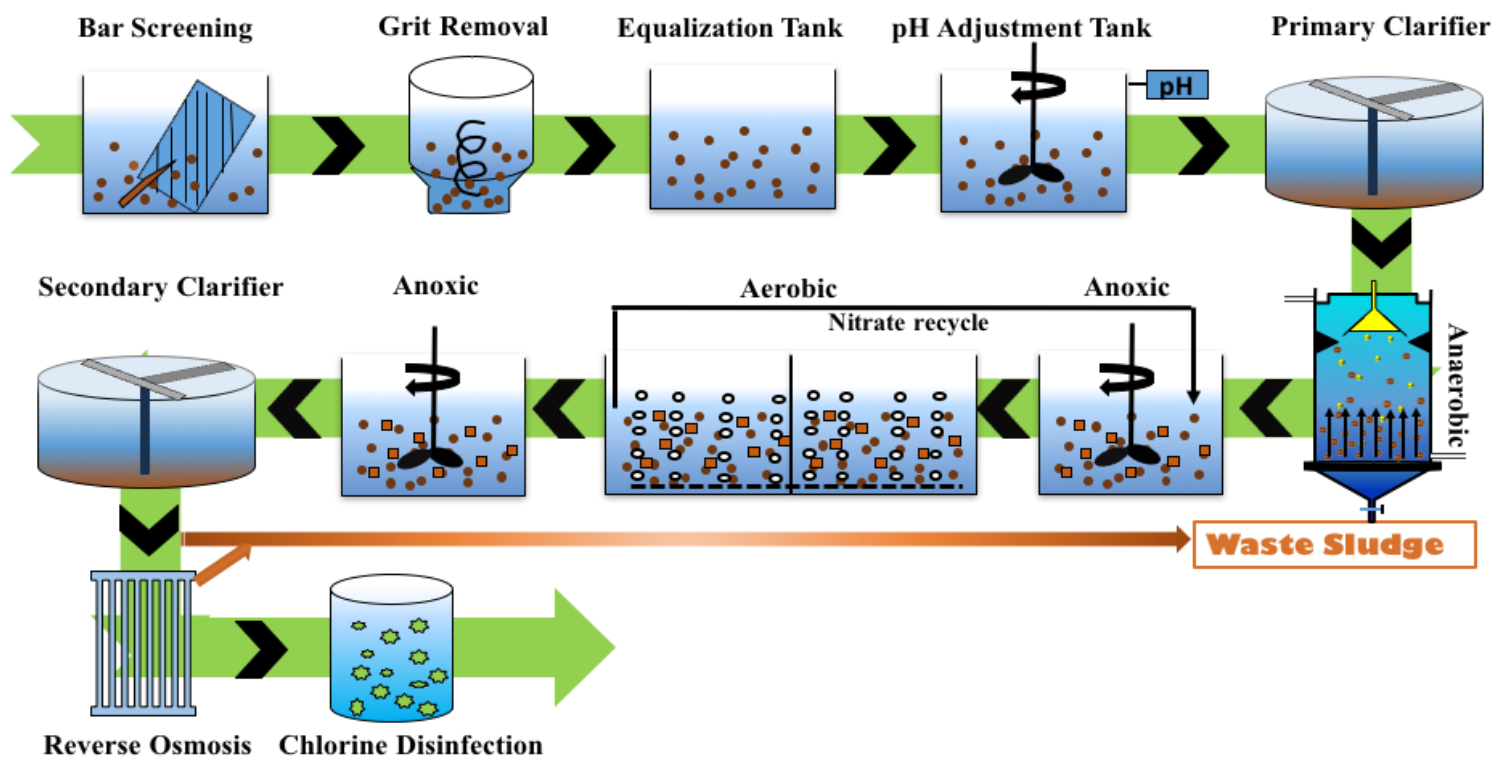

Figure 5. MBBR system with pre-anoxic and post-anoxic reactors.

wastes, can be achieved. This approach has the potential to reduce the toxicity of the contaminants and enable safe discharge of effluent. Under oxygen limiting conditions, microbes will switch to nitrate respiration and produce chemical fuels ( $\mathrm{Lu}$ et al., 2014, 2015). According to Lai and Shieh (1996), under anoxic conditions in a batch experiment, MEA is highly degraded into ammonia by using $\mathrm{NO}_{3}{ }^{-}$as an electron acceptor, and the end product is ammonia and ethanol. More than $70 \%$ of total organic carbon (TOC) in the mixed liquor can be removed within $4 \mathrm{~h}$ after the introduction of the MEA solvent.

Ndegwa et al. (2004) tested the biodegradation performance and pathways in the MEA contaminated soil under various environmental conditions. Even when the concentration of MEA is above $1,500 \mathrm{mg} / \mathrm{kg}$, the degradation rate is not impacted and microbial growth is not inhibited. Figure 4 shows the biodegradation of MEA under aerobic and anaerobic conditions. This process involves hydrolysis of MEA to ammonium and acetaldehyde. Ammonium can be further oxidized to nitrite and nitrate, then finally denitrified to $\mathrm{N}_{2}$. Acetaldehyde is degraded to ethanol and acetic acid through a hydrolysis reaction. The presence of acetic acid and ethanol can also act as an electron donor for the denitrification of nitrate. The limited oxygen in anoxic zones of soil enables the simultaneous nitrification and denitrification. The degradation rate is reduced with the decreased temperature in soil. Generally, aerobic condition provides higher biodegradation rates, whereas more energy efficient is acquired during anaerobic treatment (Botheju et al., 2011). It is a promising solution to combine aerobic, anaerobic, and anoxic treatment together.

\subsubsection{Biological Treatment Design}

Biological treatment can be carried out using various process configurations. The income wastewater requires pretreatment with bar screening, grit removal and equalization tank, then adjust $\mathrm{pH}$ values between 7.0 and 8.5 by adding alkalinity like calcium carbonate. Also, it is important to remove of toxic materials like heavy metals from the wastewater and considerate waste biodegradability, dissolved oxygen, food to microbe ratio $(\mathrm{F} / \mathrm{M}$ in the range of $0.2 \sim 1.0$, and adequate buffering (alkalinity in the range of $50 \sim 100 \mathrm{mg} / \mathrm{L}$ ). These conditions will favor the removal of total nitrogen, sulfate, and organic matter in the wastewater. Treatment requirements and process selection can be categorized according to effluent discharge water quality needs, which may range from secondary treatment for BOD removal, nitrification to achieve low effluent ammonia concentration, anoxic-aerobic processes to provide nitrogen removal, and anaerobic-anoxic-aerobic processes to provide nitrogen and sulfate removal. No matter what kind of treatment process is and how many stages are used, they all require an anaerobic zone to reduce sulfate, an aerobic zone for nitrification and an anoxic zone for denitrification and hydrolysis MEA.

Plug-flow aeration tank is suitable for aerobic nitrification with high dissolved oxygen (DO) level (> 1mg/L), long solid retention time, high microorganism number, and alkaline condition. In contrast, denitrification can only happen in anoxic condition with DO level $<0.5 \mathrm{mg} / \mathrm{L}$. Krauss et al. (2009) report that nitrification/denitrification combined with additional sand filtration is able to reduce up to $90 \%$ nitrosamine in the wastewater.

Three biological designs covering Complete-Mix Activated Sludge (CMAS), oxidation ditch, and trickling filter are presented by Nurrokhmah et al. (2013) to treat the amine reclaimer wastewater. In order to meet the landscape irrigation water standard in the United Arab Emirates (UAE), some critical parameters are tested, such as the food to microbe ratio (F/M) and volumetric loading. The results indicate that $90 \%$ of nitrogen and organic compound are removed in trickling filter 
design, and this process is defined as the most economically feasible method among these three biological designs.

Hauser et al. (2013) are the first to demonstrate the feasibility of pre-anoxic denitrification in the MBBR system. It achieves nitrogen removal of real amine waste from a PCC carbon capture facility without external carbon source apply. The biofilm system delivers $98 \%$ removal of MEA and up to $88 \%$ removal of total nitrogen. The pre-denitrification treatment system contains an anoxic reactor and then followed by an aerobic nitrification reactor. COD, MEA, and total nitrogen are efficiently removed with a hydraulic retention time (HRT) of $7 \mathrm{~h}$. This research clearly demonstrates the advantage of pre-anoxic denitrification over post-anoxic denitrification in treating MEA contaminated effluents. Pre-anoxic can utilize available organic substances derived from MEA degradation, avoiding the use of additional carbon sources to the denitrifying step. Also, pre-anoxic process is more robust towards toxic loads. Figure 5 shows the flow diagram of MBBR system with pre- and postdenitrification set up.

It is identified that avoiding the overloading of amines or other organics is curtail in the biofilm nitrogen removal of amine-based wastewater (Henry et al., 2016). However, there are other challenges hindered the commercialization of waste amine biodegradation during the carbon capture process. For instance, the microbial species can only selectively degrade the component in mixed amine waste. Nevertheless, a combination of different amine solvent may be used in the real $\mathrm{CO}_{2}$ capture plant. Besides, most of the degradation products of amine exhibit microbial toxicity. Therefore, a reliable and flexible biological treatment design is required to reduce these toxins and generate marketable chemical fuel products.

\section{Conclusions}

MEA is the most favorable solvent for chemical absorption of $\mathrm{CO}_{2}$ during the post-combustion capture process. Compared with other amine solutions, MEA has higher $\mathrm{CO}_{2}$ absorptivity and a faster reaction rate. These advantages make MEA a good candidate for large-scale industrial applications. However, the reported MEA degradation products in the laboratory experiment level cannot represent real data from the PCC pilot plant. A validate laboratory-scale model and simulation is desired by incorporating proper operations and analytical regimes into the pilot-scale carbon capture program. The heat stable salts and degradation products generated during carbon capture cause lots of troubles in the reclamation of MEA waste. It is essential to purify the solvent to maintain the capture efficiency and to reduce the environmental concerns. In the current stage, all reclamation technologies consume high energy and many limitations hinder its full applications. The extraction method developed by Karnwiboon et al. (2017) achieved HSSs removal from contaminated solvent under atmospheric pressure and relatively low temperatures. Integration of the current process or new reclaiming techniques is expected to be developed to reduce the PCC cost and improve the amine solvent recovery rate.

Amine-based waste handling difficulties substantially inhibite the commercial implementation of carbon capture tech- nologies. It is not wise to substitute the nontoxic $\mathrm{CO}_{2}$ emission with more toxic chemical compounds pollutions. In this perspective, different amine waste disposal, recycle, reuse, and chemical/biological treatments are reviewed. Of all these techniques, $\mathrm{NO}_{\mathrm{x}}$ scrubbing is a very attractive method for reusing amine wastewater due to its cost-effective and easy to operate features. Further study should address the commercialization of this technology and the impact of the accumulated impurities on the PCC plant operation. The biodegradation method is technical and economically viable at laboratory scales under various environmental conditions. However, the slow biodegradation rate is its biggest shortcoming. Thus, the primary focus should put on optimizing operational parameters and discovering the microbial strains that can destruct amine waste in a practicable degradation time range. A combination of biological treatment with the added catalyst may accelerate the bioreaction speed, which is a promising amine removal technique. Utilization of waste amine for biofuel conversion or biomass pretreatment has a growing potential in the waste handling of these toxic compounds. Its commercial availability and technical maturity make it a sustainable option for treating waste amines. More research attention should be addressed on increasing the product yields and the choice of microbial species according to different amine wastes. Biological treatment of amine-based wastewater is still on laboratory-scale, more detailed biological designs and economic analysis need to be integrated into the development of the cost-effective treatment at the industrial scale.

Acknowledgements. This research was supported by the National Key Research and Development Plan (2016YFA0601502).

\section{References}

Abu-Zahra, M.R., Abbas, Z., Singh, P., and Feron, P. (2013). Carbon dioxide post-combustion capture: solvent technologies overview, status and future directions. Materials and Processes for Energy: Communicating Current Research and Technological Developments, 1, 923-934.

Badr, S., Frutiger, J., Hungerbuehler, K., and Papadokonstantakis, S. (2017). A framework for the environmental, health and safety hazard assessment for amine-based post combustion $\mathrm{CO}_{2}$ capture. International Journal of Greenhouse Gas Control, 56, 202-220. https: //doi.org/10.1016/j.ijggc.2016.11.013.

Bello, A., and Idem, R.O. (2005). Pathways for the formation of products of the oxidative degradation of $\mathrm{CO}_{2}$-loaded concentrated aqueous monoethanolamine solutions during $\mathrm{CO}_{2}$ absorption from flue gases. Industrial and Engineering Chemistry Research, 44(4), 945969. https://doi.org/10.1021/ie049329.

Botheju, D., Glarborg, P., and Tokheim, L.A. (2012). $\mathrm{NO}_{\mathrm{x}}$ reduction using amine reclaimer wastes (ARW) generated in post combustion $\mathrm{CO}_{2}$ capture. International Journal of Greenhouse Gas Control, 10, 33-45. https://doi.org/10.1016/j.ijggc.2012.05.015.

Botheju, D., Li, Y., Hovland, J., Haugen, H.A., and Bakke, R. (2011). Biological treatment of amine wastes generated in post combustion $\mathrm{CO}_{2}$ capture. Energy Procedia, 4, 496-503. https://doi.org/10.1016 /j.egypro.2011.01.080.

Brakstad, O.G., Booth, A., Eide-Haugmo, I., Skjæran, J.A., Sørheim, K.R., Bonaunet, K., and da Silva, E.F. (2012). Seawater biodegradation of alkanolamines used for $\mathrm{CO}_{2}$-capture from natural gas. $\mathrm{In}$ - 
ternational Journal of Greenhouse Gas Control, 10, 271-277. https: //doi.org/10.1016/j.ijggc.2012.06.016.

Chen, X., Huang, G., An, C., Yao, Y., and Zhao, S. (2018). Emerging $\mathrm{N}$-nitrosamines and $\mathrm{N}$-nitramines from amine-based post-combustion $\mathrm{CO}_{2}$ capture-a review. Chemical Engineering Journal, 335, 921 -935. https://doi.org/10.1016/j.cej.2017.11.032.

Chi, S., and Rochelle, G.T. (2002). Oxidative degradation of monoethanolamine. Industrial and Engineering Chemistry Research, 41(17), 4178-4186. https://doi.org/10.1021/ie010697c.

Ciferno, J.P., Fout, T.E., Jones, A.P., and Murphy, J.T. (2009). Capturing carbon from existing coal-fired power plants. Chemical Engineering Progress, 105(4), 33.

Cummings, A.L., Smith, G.D., and Nelsen, D.K. (2007). Advances in amine reclaiming-why there's no excuse to operate a dirty amine system. In Laurance Reid Gas Conditioning Conference (Vol. 2007).

da Silva, E.F., Kolderup, H., Goetheer, E., Hjarbo, K.W., Huizinga, A., Khakharia, P., and Hyldbakk, A. (2013). Emission studies from a $\mathrm{CO}_{2}$ capture pilot plant. Energy Procedia, 37, 778-783. https://doi. org/10.1016/j.egypro.2013.05.167.

Davis, J.D. (2009). Thermal degradation of aqueous amines used for carbon dioxide capture. The University of Texas at Austin. http://hdl. handle.net/2152/6581.

Dumée, L., Scholes, C., Stevens, G., and Kentish, S. (2012). Purification of aqueous amine solvents used in post combustion $\mathrm{CO}_{2}$ capture: a review. International Journal of Greenhouse Gas Control, 10, 443-455. https://doi.org/10.1016/j.ijggc.2012.07.005.

Dutcher, B., Fan, M., and Russell, A.G. (2015). Amine-based $\mathrm{CO}_{2}$ capture technology development from the beginning of 2013-A Review. ACS Applied Materials and Interfaces, 7(4), 2137-2148. https://doi. org/10.1021/am507465f.

Eide-Haugmo, I., Brakstad, O.G., Hoff, K.A., da Silva, E.F., and Svendsen, H.F. (2012). Marine biodegradability and ecotoxicity of solvents for $\mathrm{CO}_{2}$-capture of natural gas. International Journal of Greenhouse Gas Control, 9, 184-192. https://doi.org/10.1016/ j.ijgg c.2012.03.006

ElMoudir, W., Supap, T., Saiwan, C., Idem, R., and Tontiwachwuthikul, P. (2012). Part 6: Solvent recycling and reclaiming issues. Carbon Management, 3(5), 485-509. https://doi.org/10.4155/cmt.12.55.

Feron, P.H. (2010). Exploring the potential for improvement of the energy performance of coal fired power plants with post-combustion capture of carbon dioxide. International Journal of Greenhouse Gas Control, 4(2), 152-160. https://doi.org/10.1016/j.ijggc.2009.10.018.

Fjellsbø, L.M., Verstraelen, S., Kazimirova, A., Van Rompay, A.R., Magdolenova, Z., and Dusinska, M. (2014). Genotoxic and mutagenic potential of nitramines. Environmental Research, 134, 39-45. https://doi.org/10.1016/j.envres.2014.06.008.

Fostås, B., Gangstad, A., Nenseter, B., Pedersen, S., Sjøvoll, M., and Sørensen, A.L. (2011). Effects of $\mathrm{NO}_{\mathrm{x}}$ in the flue gas degradation of MEA. Energy Procedia, 4, 1566-1573. https://doi.org/10.1016/j.eg ypro.2011.02.026.

Ghayur, A., Verheyen, T.V., and Meuleman, E. (2019). Biological and chemical treatment technologies for waste amines from $\mathrm{CO}_{2}$ capture plants. Journal of Environmental Management, 241, 514-524. https: //doi.org/10.1016/j.jenvman.2018.07.033.

Gjernes, E., Helgesen, L.I., and Maree, Y. (2013). Health and environmental impact of amine based post combustion $\mathrm{CO}_{2}$ capture. Energy Procedia, 37, 735-742. https://doi.org/10.1016/j.egypro.201 3.05.162.

Goff, G.S., and Rochelle, G.T. (2004). Monoethanolamine degradation: $\mathrm{O}_{2}$ mass transfer effects under $\mathrm{CO}_{2}$ capture conditions. Industrial and Engineering Chemistry Research, 43(20), 6400-6408. https:// doi.org/10.1021/ie0400245.

Gouedard, C., Picq, D., Launay, F., and Carrette, P.L. (2012). Amine degradation in $\mathrm{CO}_{2}$ capture. I. A review. International Journal of Greenhouse Gas Control, 10, 244-270. https://doi.org/10.1016/j.ij ggc.2012.06.015
Guan, Y., Huang, G., Liu, L., Huang, C.Z., and Zhai, M. (2019). Ecological network analysis for an industrial solid waste metabolism system. Environmental Pollution, 244, 279-287. https://doi.org/10.1 016/j. envpol.2018.10.052.

Gwak, G., Kim, D.I., Kim, J., Zhan, M., and Hong, S. (2019). An integrated system for $\mathrm{CO}_{2}$ capture and water treatment by forward osmosis driven by an amine-based draw solution. Journal of Membrane Science, 581, 9-17. https://doi.org/10.1016/j.memsci.2019. 03.036

Harris, J.M., and Roach, B. (2016). Global Climate Change: Science and Economics.

Hauser, I., Einbu, A., Østgaard, K., Svendsen, H.F., and Cervantes, F.J. (2013). Biodegradation of amine waste generated from post-combustion $\mathrm{CO}_{2}$ capture in a moving bed biofilm treatment system. $B i$ otechnology Letters, 35(2), 219-224. https://doi.org/10.1007/s1052 9-012-1073-6

Haws, R. (2001). Contaminants in amine gas treating. CCR Technologies Inc., 11375.

Henni, A., Rayer, A.V., Sumon, K.Z., Sema, T., Idem, R., and Tontiwachwuthikul, P. (2013). Solubility of $\mathrm{CO}_{2}$ in reactive solvents for post-combustion $\mathrm{CO}_{2}$ capture. Future Science Ltd.

Henry, I.A. (2016). Biological Nitrogen Removal of Effluents from Amine-based $\mathrm{CO}_{2}$ Capture Plants: Screening, Feasibility and Limitations. http://hdl.handle.net/11250/2428703.

Henry, I.A., Kowarz, V., and Østgaard, K. (2017). Aerobic and anoxic biodegradability of amines applied in $\mathrm{CO}_{2}$-capture. International Journal of Greenhouse Gas Control, 58, 266-275. https://doi.org /10.1016/j.ijggc.2017.02.004.

Karnwiboon, K., Saiwan, C., Idem, R., Supap, T., and Tontiwachwuthikul, P. (2017). Solvent Extraction of Degradation Products in Amine Absorption Solution for $\mathrm{CO}_{2}$ Capture in Flue Gases from Coal Combustion: Effect of Amines. Energy Procedia, 114, 19801985. https://doi.org/10.1016/j.egypro.2017.03.1331.

Kim, D.J., Lim, Y., Cho, D., and Rhee, I.H. (2010). Biodegradation of monoethanolamine in aerobic and anoxic conditions. Korean Journal of Chemical Engineering, 27(5), 1521-1526. https://doi.org/ 10.1007/s11814-010-0285-5.

Kimura, H., Kubo, T., Shimada, M., Kitamura, H., Fujita, K., Suzuki, K., and Akai, M. (2017). Environmental Risk Assessment of MEA and its Degradation Products from Post-combustion $\mathrm{CO}_{2}$ Capture Pilot Plant: Drafting Technical Guidelines. Energy Procedia, 114, 6490-6500. https://doi.org/10.1016/j.egypro.2017.03.1785.

Knudsen, J.N., Jensen, J.N., Vilhelmsen, P.J., and Biede, O. (2009). Experience with $\mathrm{CO}_{2}$ capture from coal flue gas in pilot-scale: Testing of different amine solvents. Energy Procedia, 1(1), 783-790. https://doi.org/10.1016/j.egypro.2009.01.104.

Krauss, M., Longrée, P., Dorusch, F., Ort, C., and Hollender, J. (2009). Occurrence and removal of $\mathrm{N}$-nitrosamines in wastewater treatment plants. Water Research, 43(17), 4381-4391. https://doi.org/10.1016 /j.watres.2009.06.048.

Kumar, S., Cho, J.H., and Moon, I. (2014). Ionic liquid-amine blends and $\mathrm{CO}_{2} \mathrm{BOLs}$ : prospective solvents for natural gas sweetening and $\mathrm{CO}_{2}$ capture technology-a review. International Journal of Greenhouse Gas Control, 20, 87-116. https://doi.org/10.1016/j.ijggc.201 3.10.019.

Låg, M., Lindeman, B., Instanes, C., Brunborg, G., and Schwarze, P. (1984). Health effects of amines and derivatives associated with $\mathrm{CO}_{2}$ capture. IARC Sci Publ, 57, 3-22.

Lai, B., and Shieh, W.K. (1996). Batch monoethylamine degradation via nitrate respiration. Water Research, 30(10), 2530-2534. https:// doi.org/10.1016/0043-1354(96)00107-8.

Lawal, O., Bello, A., and Idem, R. (2005). The role of methyl diethanolamine (MDEA) in preventing the oxidative degradation of $\mathrm{CO}_{2}$ loaded and concentrated aqueous monoethanolamine (MEA)-MDEA blends during $\mathrm{CO}_{2}$ absorption from flue gases. Industrial and Engineering Chemistry Research, 44(6), 1874-1896. https://doi.org/ 
10.1021/ie049261y.

Lepaumier, H., da Silva, E.F., Einbu, A., Grimstvedt, A., Knudsen, J. N., Zahlsen, K., and Svendsen, H.F. (2011). Comparison of MEA degradation in pilot-scale with lab-scale experiments. Energy Procedia, 4, 1652-1659. https://doi.org/10.1016/j.egypro.2011.02.037.

Lepaumier, H., Picq, D., and Carrette, P.L. (2009). New amines for $\mathrm{CO}_{2}$ capture. I. Mechanisms of amine degradation in the presence of $\mathrm{CO}_{2}$. Industrial and Engineering Chemistry Research, 48(20), 9061-9067. https://doi.org/10.1021/ie900472x.

Leung, D.Y., Caramanna, G., and Maroto-Valer, M.M. (2014). An overview of current status of carbon dioxide capture and storage technologies. Renewable and Sustainable Energy Reviews, 39, 426443. https://doi.org/10.1016/j.rser.2014.07.093.

Li, Y. (2008). Biodegradation of waste amines under anaerobic, microaerobic and aerobic conditions (Master's thesis, Høgskolen i Telemark). http://hdl.handle.net/11250/2439073.

Liang, Z.H., Rongwong, W., Liu, H., Fu, K., Gao, H., Cao, F., and Nath, D. (2015). Recent progress and new developments in post-combustion carbon-capture technology with amine based solvents. International Journal of Greenhouse Gas Control, 40, 26-54. https:// doi.org/10.1016/j.ijggc.2015.06.017.

Liao, X., Bei, E., Li, S., Ouyang, Y., Wang, J., Chen, C., and Suffet, I.M. (2015). Applying the polarity rapid assessment method to characterize nitrosamine precursors and to understand their removal by drinking water treatment processes. Water Research, 87, 292-298. https://doi.org/10.1016/j.watres.2015.09.040.

Liu, L., Huang, C.Z., Huang, G., Baetz, B., and Pittendrigh, S.M. (2018). How a carbon tax will affect an emission-intensive economy: A case study of the Province of Saskatchewan, Canada. Energy, 159, 817-826. https://doi.org/10.1016/j.energy.2018.06.163.

Liuzinas, R., Jankevicius, K., Salkauskas, M., Jakubenas, R., Paskevicius, A., and Mikalajunas, M. (2007). Biological method for the detoxification of spent monoethanolamine solutions. Proceedings of the Kalmar Eco-Tech, 7, 853-60.

Lu, H., Chandran, K., and Stensel, D. (2014). Microbial ecology of denitrification in biological wastewater treatment. Water Research, 64, 237-254. https://doi.org/10.1016/j.watres.2014.06.042.

Lu, X., Zhen, G., Estrada, A.L., Chen, M., Ni, J., Hojo, T., and Li, Y.Y. (2015). Operation performance and granule characterization of upflow anaerobic sludge blanket (UASB) reactor treating wastewater with starch as the sole carbon source. Bioresource Technology, 180, 264-273. https://doi.org/10.1016/j.biortech.2015.01.010.

MacDowell, N., Florin, N., Buchard, A., Hallett, J., Galindo, A., Jackson, G., and Fennell, P. (2010). An overview of $\mathrm{CO}_{2}$ capture technologies. Energy and Environmental Science, 3(11), 1645-1669. https://doi.org/10.1039/C004106H.

Mazari, S.A., Alaba, P., and Saeed, I.M. (2019). Formation and elimination of nitrosamines and nitramines in freshwaters involved in post-combustion carbon capture process. Journal of Environmental Chemical Engineering, 7(3), 103111. https://doi.org/10.1016 /j.je ce.2019.103111.

McCann, N., Phan, D., Wang, X., Conway, W., Burns, R., Attalla, M., and Maeder, M. (2009). Kinetics and mechanism of carbamate formation from $\mathrm{CO}_{2}(\mathrm{aq})$, carbonate species, and monoethanolamine in aqueous solution. The Journal of Physical Chemistry A, 113(17), 5022-5029. https://doi.org/10.1021/jp810564z.

Mrklas, O., Chu, A., Lunn, S., and Bentley, L.R. (2004). Biodegradation of monoethanolamine, ethylene glycol and triethylene glycol in laboratory bioreactors. Water, Air, and Soil Pollution, 159(1), 249263. https://doi.org/10.1023/B:WATE.0000049178.93865.d4.

Ndegwa, A.W., Wong, R.C., Chu, A., Bentley, L.R., and Lunn, S.R. (2004). Degradation of monoethanolamine in soil. Journal of Environmental Engineering and Science, 3(2), 137-145. https://doi.org/ 10.1139/s03-074

Nurrokhmah, L., Mezher, T., and Abu-Zahra, M.R. (2013). Evaluation of handling and reuse approaches for the waste generated from
MEA-based $\mathrm{CO}_{2}$ capture with the consideration of regulations in the UAE. Environmental Science \& Technology, 47(23), 13644-13651. https://doi.org/10.1021/es4027198.

Ohtaguchi, K., and Wijanarko, A. (2002). Elevation of the efficiency of cyanobacterial carbon dioxide removal by monoethanolamine solution. Technology, 8(4-5), 267-286.

Ohtaguchi, K., and Yokoyama, T. (1997). The synthesis of alternatives for the bioconversion of waste-monoethanolamine from large-scale $\mathrm{CO}_{2}$-removal processes. Energy Conversion and Management, 38, S539-S544. https://doi.org/10.1016/S0196-8904(96)00324-X.

Ohtaguchi, K., Koide, K., and Yokoyama, T. (1995). An ecotechnology-integrated MEA process for $\mathrm{CO}_{2}$-removal. Energy Conversion and Management, 36(6-9), 401-404. https://doi.org/10.1016/01968904(95)00030-H.

Puxty, G., Rowland, R., Allport, A., Yang, Q., Bown, M., Burns, R., and Attalla, M. (2009). Carbon dioxide postcombustion capture: a novel screening study of the carbon dioxide absorption performance of 76 amines. Environmental Science \& Technology, 43(16), 6427 6433. https://doi.org/10.1021/es901376a.

Rao, A.B., and Rubin, E.S. (2002). A technical, economic, and environmental assessment of amine-based $\mathrm{CO}_{2}$ capture technology for power plant greenhouse gas control. Environmental Science \& Technology, 36(20), 4467-4475. https://doi.org/10.1021/es0158861.

Ravnum, S., Rundén-Pran, E., Fjellsbø, L. M., and Dusinska, M. (2014). Human health risk assessment of nitrosamines and nitramines for potential application in $\mathrm{CO}_{2}$ capture. Regulatory Toxicology and Pharmacology, 69(2), 250-255. https://doi.org/10.1016 /j. yrtph.2014.04.002.

Reynolds, A.J., Verheyen, T.V., Adeloju, S.B., Meuleman, E., and Feron, P. (2012). Towards commercial scale postcombustion capture of $\mathrm{CO}_{2}$ with monoethanolamine solvent: key considerations for solvent management and environmental impacts. Environmental Science \& Technology, 46(7), 3643-3654. https://doi.org/10.1021 les204051s.

Reynolds, A.J., Verheyen, T.V., and Meuleman, E. (2016). Degradation of amine-based solvents. In Absorption-Based Post-combustion Capture of Carbon Dioxide. Woodhead Publishing, 399-423.

Rohr, A.C., McDonald, J.D., Kracko, D., Doyle-Eisele, M., Shaw, S. L., and Knipping, E.M. (2013). Potential toxicological effects of amines used for carbon capture and storage and their degradation products. Energy Procedia, 37, 759-768. https://doi.org/10.1016/ j. egypro.2013.05.165

Romeo, L.M., Bolea, I., and Escosa, J.M. (2008). Integration of power plant and amine scrubbing to reduce $\mathrm{CO}_{2}$ capture costs. Applied Thermal Engineering, 28(8-9), 1039-1046. https://doi.org/10.1016/ j.applthermaleng.2007.06.036.

Seifert, K., Thiel, M., Wicher, E., Wlodarczak, M., and Laniecki, M. (2012). Microbiological methods of hydrogen generation. Biogas, 223-250.

Shao, R., and Stangeland, A. (2009). Amines Used in $\mathrm{CO}_{2}$ Capture. The Bellona Foundation Technical Report, Oslo, Norway.

Sharp, J.O., Wood, T.K., and Alvarez- Cohen, L. (2005). Aerobic biodegradation of N-nitrosodimethylamine (NDMA) by axenic bacterial strains. Biotechnology and Bioengineering, 89(5), 608-618. https://doi.org/10.1002/bit.20405.

Singh, P., Niederer, J.P., and Versteeg, G.F. (2009). Structure and activity relationships for amine-based $\mathrm{CO}_{2}$ absorbents-II. Chemical Engineering Research and Design, 87(2), 135-144. https://doi.org/ 10.1016/S1750-5836(07)00015-1.

Song, P., Huang, G., An, C., Shen, J., Zhang, P., Chen, X., and Sun, C. (2018). Treatment of rural domestic wastewater using multi-soillayering systems: Performance evaluation, factorial analysis and numerical modeling. Science of the Total Environment, 644, 536546. https://doi.org/10.1016/j.scitotenv.2018.06.331.

Strazisar, B.R., Anderson, R.R., and White, C.M. (2001). Degradation of monoethanolamine used in carbon dioxide capture from flue gas 
of a coal-fired electric power generating station. National Energy Technology Laboratory, Pittsburgh, PA, USA.

Strazisar, B.R., Anderson, R.R., and White, C.M. (2003). Degradation pathways for monoethanolamine in a $\mathrm{CO}_{2}$ capture facility. Energy and Fuels, 17(4), 1034-1039. https://doi.org/10.1021/ef020272i.

Thitakamol, B., Veawab, A., and Aroonwilas, A. (2007). Environmental impacts of absorption-based $\mathrm{CO}_{2}$ capture unit for post-combustion treatment of flue gas from coal-fired power plant. International Journal of Greenhouse Gas Control, 1(3), 318-342. https://doi.org/ 10.1016/S1750-5836(07)00042-4.

Thompson, J.G., Bhatnagar, S., Combs, M., Abad, K., Onneweer, F., Pelgen, J., and Liu, K. (2017). Pilot testing of a heat integrated 0.7 $\mathrm{MWe} \mathrm{CO}_{2}$ capture system with two-stage air-stripping: Amine degradation and metal accumulation. International Journal of Greenhouse Gas Control, 64, 23-33. https://doi.org/10.1016/j.ijggc.201 7.07.004.

Veltman, K., Singh, B., and Hertwich, E.G. (2010). Human and environmental impact assessment of postcombustion $\mathrm{CO}_{2}$ capture focus-ing on emissions from amine-based scrubbing solvents to air. Environmental Science \& Technology, 44(4), 1496-1502. https://doi. org/10.1021/es902116r.

Volkov, A., Vasilevsky, V., Bazhenov, S., Volkov, V., Rieder, A., Unterberger, S., and Schallert, B. (2013). Heat-stable salts removal from alkanolamine solution by electrodialysis. In Proceedings of the 7th Trondheim CCS Conference, Trondheim, Norway.

Wagner, E.D., Osiol, J., Mitch, W.A., and Plewa, M.J. (2014). Comparative in vitro toxicity of nitrosamines and nitramines associated with amine-based carbon capture and storage. Environmental Science \& Technology, 48(14), 8203-8211. https://doi.org/10.1021/ es5018009.

Wang, S., Hovland, J., and Bakke, R. (2013). Efficiency of the anaerobic digestion of amine wastes. Biotechnology Letters, 35(12), 205 2060. https://doi.org/10.1007/s10529-013-1296-1.
Wang, S., Hovland, J., Brooks, S., and Bakke, R. (2014). Detoxifying $\mathrm{CO}_{2}$ capture reclaimer waste by anaerobic digestion. Applied Biochemistry and Biotechnology, 172(2), 776-783. https://doi.org/10. 1007/s12010-013-0587-2.

Wang, T., Hovland, J., and Jens, K.J. (2015). Amine reclaiming technologies in post-combustion carbon dioxide capture. Journal of Environmental Sciences, 27, 276-289. https://doi.org/10.1016/j.jes.20 14. 06.037.

Xie, Y.L., Xia, D.X., Ji, L., and Huang, G.H. (2018). An inexact stochastic-fuzzy optimization model for agricultural water allocation and land resources utilization management under considering effective rainfall. Ecological Indicators, 92, 301-311. https://doi.org/10. 1016/j.ecolind.2017.09.026.

Xin, X., Huang, G., An, C., Huang, C., Weger, H., Zhao, S., and Rosendahl, S. (2018). Insights into the toxicity of triclosan to green microalga Chlorococcum sp. using synchrotron-based fourier transform infrared spectromicroscopy: biophysiological analyses and roles of environmental factors. Environmental Science \& Technology, 52(4), 2295-2306. https://doi.org/10.1021/acs.est.7b05533.

Woods, J., Tipper, R., Brown, G., Diaz-Chavez, R., Lovell, J., and de Groot, P. (2006). Evaluating the Sustainability of Co-firing in the UK. Report URN, 6, 1960.

$\mathrm{Xu}, \mathrm{Q}$., and Rochelle, G.T. (2009). Solvent reclaiming by crystallization of potassium sulfate. Energy Procedia, 1(1), 1205-1212. https: //doi.org/10.1016/j.egypro.2009.01.158.

Zhang, X., He, X., and Gundersen, T. (2013). Post-combustion carbon capture with a gas separation membrane: parametric study, capture cost, and exergy analysis. Energy and Fuels, 27(8), 4137-4149. https://doi.org/10.1021/ef3021798.

Zhu, G., Peng, Y., Li, B., Guo, J., Yang, Q., and Wang, S. (2008). Biological removal of nitrogen from wastewater. In Reviews of environmental contamination and toxicology (pp. 159-195). https://doi. org/10.1007/978-0-387-71724-1_5. 